\title{
Effects of group speech-language pathology actions related to teachers' vocal health: an integrative literature review
}

\author{
Patrícia Brianne da Costa Penha1 \\ https://orcid.org/0000-0002-2385-4346 \\ Camila Macêdo Araújo de Medeiros ${ }^{2}$ \\ https://orcid.org/0000-0003-3340-1807 \\ Anna Carolina D'ucarmo Bezerra' \\ https://orcid.org/0000-0002-8455-7046 \\ Maria Helimara de Medeiros ${ }^{3}$ \\ https://orcid.org/0000-0001-8718-5287 \\ Luyênia Kérlia Gomes Martins ${ }^{4}$ \\ https://orcid.org/0000-0003-0399-527X \\ Lorena Sampaio Duarte 4 \\ https://orcid.org/0000-0002-0732-2024 \\ Gabriella Lucena Feitosa ${ }^{4}$ \\ https://orcid.org/0000-0002-5192-2203 \\ Maria Fabiana Bonfim de Lima Silva ${ }^{5}$ \\ https://orcid.org/0000-0002-2348-8374
}

Universidade Federal da Paraíba - UFPB, Programa Associado de Pós-Graduação em Fonoaudiologia, João Pessoa, Paraíba, Brasil.

Universidade Federal da Paraíba, UFPB, Programa de Pós-Graduação em Linguística, João Pessoa, Paraíba, Brasil.

Universidade Federal do Rio Grande do Norte - UFRN, Programa Associado de Pós-Graduação em Fonoaudiologia, Natal, Rio Grande do Norte, Brasil.

Universidade Federal da Paraíba - UFPB, João Pessoa, Paraíba, Brasil.

Universidade Federal da Paraíba - UFPB, Departamento de Fonoaudiologia, João Pessoa, Paraíba, Brasil.

Study conducted at the Universidade Federal da Paraíba - UFPB, Departamento de Fonoaudiologia, João Pessoa, Paraíba, Brazil.

Conflict of interests: Nonexistent

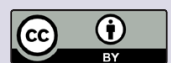

Received on: March 7, 2019

Approved on: September 5, 2019

Corresponding address:

Maria Fabiana Bonfim Lima Silva

Departamento de Fonoaudiologia

Centro de Ciências da Saúde

Cidade Universitária - Campus I,

Castelo Branco

CEP: 58051-900 - João Pessoa, Paraíba, Brasil

E-mail: fbl_fono@yahoo.com.br

\section{ABSTRACT}

Objective: to conduct an integrative literature review on the effect of group speech-language pathology actions related to teachers' vocal health, and to identify, evaluate and discuss therapeutic approaches, assessment instruments, duration of actions, number of meetings, and their effectiveness, from articles published between 2007 and 2017.

Methods: this research was conducted using the "voice", "faculty", "psychotherapy group" and "voice training" descriptors, and their corresponding descriptors in Portuguese, using the databases: LILACS, SciELO and PubMed.

Results: the search resulted in 1,944 papers. After the selection, 9 studies fulfilled the inclusion and exclusion criteria.

Conclusion: the group speech-language pathology actions related to teachers' vocal health have an effect on the voice-related quality of life, reducing the vocal and emotional symptoms caused by work-related factors. The eclectic therapeutic approach was the most used one, and there were variations in the duration of actions and number of meetings among the studies. In terms of assessment instruments, the self-assessment of voice and the auditory-perceptual analysis were the most highlighted ones. Furthermore, most studies considered the results of their actions as effective.

Keywords: Voice; Faculty; Group Processes; Voice Training; Health Promotion; Speech Therapy 


\section{INTRODUCTION}

Voice is the essential element of human communication, and its use is indispensable for professionals that use it as a tool in their jobs, as teachers ${ }^{1-3}$. Teachers are one of the most investigated categories in the field of voice, since they show a high prevalence of voice disorders, due to several work-related factors and the heavy use of their voices ${ }^{4-6}$.

When teachers develop a voice disorder due to their job, several aspects of their social and professional life are affected $^{7}$. Some of the implications related to voice disorders are the performance reduction in the classroom, self-esteem and emotional problems, negative influence on teaching-learning, among others 7-10. In the literature ${ }^{2}$, studies reveal that, due to risks of the development of occupational voice disorders, teachers often consider to change their profession to have a better quality of life.

A literature review ${ }^{4}$ on studies conducted in Brazil on teachers' voice revealed that, from 500 studies under analysis, only $14 \%$ focused on the evaluation of the effects of voice intervention programs. On the other hand, $86 \%$ of those studies intended to conduct evaluations. Those results reveal the small number of studies that aim at investigating the effect of promotion actions and prevention of voice disorders in teachers.

However, when actions related to teachers' vocal heath are promoted, the literature indicates that there are positive contributions. For example, a significant reduction of voice signs and symptoms, an improvement of the quality of life and voice at work, advances in the ability to identify inappropriate vocal behaviors, and the learning of strategies to reduce unpleasant proprioceptive feelings ${ }^{11-13}$. Furthermore, teachers that participate in those interventions feel satisfied and report how the acquired learning is important to develop the professional activity more healthily and with more vocal well-being ${ }^{14}$.

Mostly, those speech-language pathology actions are conducted at school, in order to make teachers feel more comfortable to attend the activities. In addition, they promote discussions about environmental and organizational factors in the schools ${ }^{12,15,16}$. Therefore, the group actions related to vocal health are indicated in literature ${ }^{16-18}$ as a positive therapy to participants.

In relation to the contributions of group therapy with actions of vocal health, it is possible to verify that it makes teachers aware of the problem, and it promotes reflection, discussion, experience sharing, and the construction of shared knowledge among groups, creating a support network ${ }^{12,16,19}$.

In the individual or group intervention, it is possible to use three different types of therapeutic approaches: direct, indirect and eclectic. The direct approach is characterized by the realization of specific vocal techniques and exercises focused in breathing, phonation, resonance and articulation, in order to modify the aspects of voice production and to induce a better phonation pattern. The indirect approach is characterized by recommendations and guidelines on vocal hygiene, with the objective of accomplishing learning and vocal care. Both approaches are not mutually exclusive and can be associated, therefore constituting the eclectic approach ${ }^{20,21}$.

Literature review studies ${ }^{21,22}$ reveal that, in speech-language pathology actions performed with teachers, the eclectic approach is the most common. The most highlighted topics are vocal behaviors, vocal health, hygiene care and habits, vocal techniques and exercises, and understandings of the anatomy and physiology of vocal production.

In order to verify possible accomplishments from the promoted speech-language pathology intervention, it is necessary to conduct a voice assessment ${ }^{23,24}$. It could be carried out using auditory-perceptual, acoustic, aerodynamic, laryngeal or self-reported measures, in pre-or post-intervention. Thus, it is possible to compare whether the conducted action showed potential or not to promote benefits to vocal health.

The group intervention allows the creation of a space to dialog and face problems, contributing both emotionally and socially to the rehabilitation of individuals ${ }^{17,19}$. In the last years, this intervention has been highlighted in Speech-Language Pathology. Therefore, an investigation of how this intervention has been developed and applied and its benefits to teachers' vocal health is relevant to further understand this practice in the field of voice.

Thus, this integrative literature review aims at verifying the effects of group speech-language pathology actions related to teachers' vocal health, and to identify, evaluate and discuss therapeutic approaches, assessment instruments, duration of actions/number of meetings, and their effectiveness, from articles published between 2007 and 2017.

\section{METHODS}

An integrative literature review was carried out with the objective of identifying, analyzing and synthetizing 
results from studies that analyze the same topic, improving the understanding of what has been investigated in the field of this particular topic ${ }^{25}$.

This research was guided by the following question: do group speech-language pathology actions affect the vocal health and vocal well-being? The articles were selected from the databases Latin American and Caribbean Health Sciences Literature (LILACS), Scientific Electronic Library Online (SciELO) and Public Medicine Library (PubMed). Those databases were selected because they show high scientific credibility and a relevant number of publications investigating teachers.

The inclusion and exclusion criteria were: papers published from 2007 to 2017, with proposals of speech-language pathology actions in vocal health, conducted in group, with teachers from the municipal or state school system, published in Portuguese or English, and with the full paper available for reading. A previous search of publications related to group therapy for teachers' voice was performed, and it was observed that there was a higher number of papers in the period covered by this study.

Considering the research question, the Health Sciences Descriptors (DeCS) was used to select the descriptors that would potentially refer to studies on this topic. The descriptors used in this study and their respective combinations, in Portuguese and English, were respectively: "voz e docentes" - "voice and faculty", "voz e terapia de grupo" - "voice and psychotherapy group", "voz e treinamento da voz" - "voice and voice training", "treinamento da voz e terapia de grupo" - "voice training and psychotherapy group", "terapia de grupo e docentes" - "psychotherapy group and faculty" and "treinamento da voz e docentes" - "voice training and faculty". Moreover, the following filters were used to help the search: articles published from 2007 to 2017, articles, in Portuguese and English, and available for reading. The total number of articles selected in this integrative review was 1,944 (307 from LILACS, 289 from SciELO, and 1,348 from PubMed). The flowchart of the selection procedure is shown in Figure 1.

The search in the databases and the selection procedure were performed independently, from

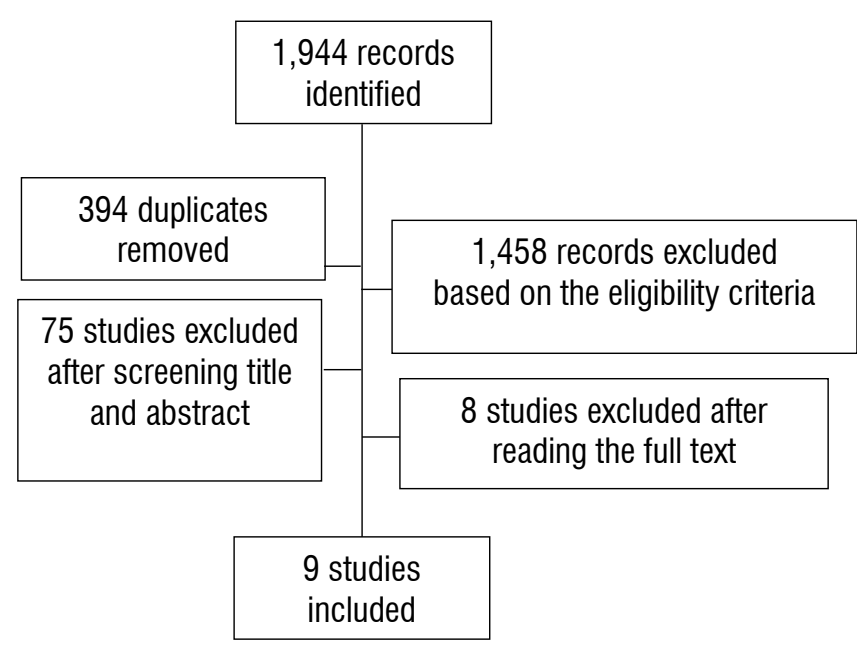

Figure 1. Flowchart of the selection of studies

September 2017 to November 2017, by two researchers, which were blinded. In case of disagreement between the examiners, there was a discussion based on the inclusion criteria.

The initial search resulted in 1,944 articles. 394 of these articles were excluded because they were duplicates, 1,458 because of the eligibility criteria, 75 because, based on the title and abstract, they did not meet the inclusion criteria or were not related to the research topic, and 8 were excluded after reading the full-text. The final selection resulted in 9 articles to be analyzed in this review.

The selected studies were analyzed and the following data were extracted from them: 1) author/ year; 2) location/type of study; 3) sample; 4) objective; 5) type of therapeutic approach; 6) assessment instrument in pre-and post-intervention; 7) duration of actions and number of meetings; and 8) intervention effectiveness, as Figure 2 shows.

It is important to highlight that the intervention effectiveness in each study was based on the report of the authors themselves, with the development of the proposed actions.

Next, in the literature review, the topics are divided into: therapeutic approaches, assessment instrument in pre-and post-intervention, duration of actions and number of meetings, and intervention effectiveness. 


\begin{tabular}{|c|c|c|c|c|c|c|c|c|}
\hline $\mathrm{N}^{0}$ & $\begin{array}{l}\text { Authorl } \\
\text { Year }\end{array}$ & $\begin{array}{l}\text { Location/type } \\
\text { of study }\end{array}$ & Sample (n) & Objective & $\begin{array}{l}\text { Type of } \\
\text { therapeutic } \\
\text { approach }\end{array}$ & $\begin{array}{l}\text { Assessment instrument in } \\
\text { pre-and post-intervention }\end{array}$ & $\begin{array}{c}\text { Duration of } \\
\text { actions and } \\
\text { number of } \\
\text { meetings }\end{array}$ & $\begin{array}{l}\text { Intervention } \\
\text { effectiveness }\end{array}$ \\
\hline 1 & $\begin{array}{l}\text { Xavier, } \\
\text { Santos and } \\
\text { Silva (2013) }\end{array}$ & $\begin{array}{c}\text { Brazil/PE } \\
\text { Quantitative } \\
\text { and qualitative } \\
\text { approaches in } \\
\text { combination }\end{array}$ & $27 ㅇ ㅜ$ & $\begin{array}{l}\text { To conduct a group action from } \\
\text { the Family Health Support Center } \\
\text { perspective, aiming at teachers' } \\
\text { health promotion, and to verify } \\
\text { their perception in relation to the } \\
\text { action that was conducted. } \\
\end{array}$ & Eclectic & \begin{tabular}{|c|} 
Pre:vocal history \\
Post: participants' self- \\
assessment questionnaire \\
about speech-language \\
pathology actions and vocal \\
symptoms. \\
\end{tabular} & $\begin{array}{l}40-60 \text { min } \\
6 \text { biweekly } \\
\text { meetings }\end{array}$ & Yes \\
\hline 2 & $\begin{array}{c}\text { Ribas, } \\
\text { Penteado } \\
\text { and García- } \\
\text { Zapata (2014) }\end{array}$ & $\begin{array}{l}\text { Brazil/GO } \\
\text { Quasi- } \\
\text { experimental } \\
\text { study }\end{array}$ & $\begin{array}{c}20 \\
14+/ 6 \AA\end{array}$ & $\begin{array}{l}\text { To verify the impact of a speech- } \\
\text { language pathology action on } \\
\text { teachers' voice-related quality } \\
\text { of life }\end{array}$ & Eclectic & \begin{tabular}{|} 
Pre and post:Protocol of \\
Vocal Complaints and the \\
Brazilian Voice-Related \\
Quality of Life questionnaire.
\end{tabular} & $\begin{array}{l}45-50 \text { min } \\
3 \text { meetings } \\
\text { (one meeting } \\
\text { per month) } \\
\end{array}$ & Partial \\
\hline 3 & $\begin{array}{l}\text { Silverio et al. } \\
\quad(2008)\end{array}$ & $\begin{array}{l}\text { Brazil/SP } \\
\text { Longitudinal } \\
\text { study }\end{array}$ & $13 q$ & $\begin{array}{l}\text { To analyze the complaints, } \\
\text { laryngeal symptoms, habits } \\
\text { related to vocal performance and } \\
\text { teachers' voice, before and after } \\
\text { their participation in groups of } \\
\text { experience in voice. }\end{array}$ & Eclectic & \begin{tabular}{|c|} 
Pre:Questionnaire about \\
vocal complaints, laryngeal \\
symptoms, vocal habits, \\
auditory-perceptual analysis \\
(GRBASI) and laryngological \\
evaluation \\
\\
Post: Auditory-perceptual \\
analysis (GRBASI). \\
\end{tabular} & $\begin{array}{c}60 \text { min } \\
12 \text { meetings }\end{array}$ & Yes \\
\hline 4 & $\begin{array}{l}\text { Luchesi, } \\
\text { Mourão and } \\
\text { Kitamura } \\
\text { (2012) }\end{array}$ & $\begin{array}{l}\text { Brazil/SP } \\
\text { Longitudinal } \\
\text { study }\end{array}$ & $5 q$ & $\begin{array}{c}\text { To analyze teachers' vocal and } \\
\text { articulatory parameters, before } \\
\text { and after a vocal improvement } \\
\text { program. }\end{array}$ & Eclectic & \begin{tabular}{|c|} 
Pre: auditory-perceptual \\
analysis (VAS), acoustic \\
analysis and laryngological \\
evaluation. \\
Post: auditory-perceptual \\
analysis (VAS)and acoustic \\
analysis. \\
\end{tabular} & $\begin{array}{l}1 \text { hour and } 30 \\
\min \\
12 \text { weekly } \\
\text { meetings }\end{array}$ & Partial \\
\hline 5 & $\begin{array}{l}\text { Trigueiro et al. } \\
\quad(2015)\end{array}$ & $\begin{array}{l}\text { Brazil/PB } \\
\text { Case study }\end{array}$ & 90 & $\begin{array}{l}\text { To describe participants' } \\
\text { experience in the extension project } \\
\text { called Educando o educador: } \\
\text { promovendo a saúde ocupacional } \\
\text { do professor (Educating the } \\
\text { educator: promoting teachers' } \\
\text { occupational health) }\end{array}$ & Eclectic & - & $\begin{array}{l}2 \text { hours } \\
\text { One meeting }\end{array}$ & Yes \\
\hline 6 & $\begin{array}{l}\text { Almeida et al. } \\
\quad(2012)\end{array}$ & $\begin{array}{c}\text { Brazil/CE } \\
\text { Action research }\end{array}$ & $\begin{array}{c}12 \\
119 / 1 \sigma^{\lambda}\end{array}$ & $\begin{array}{l}\text { To explore the health situation of } \\
\text { public school teachers, through } \\
\text { the lens of a physiotherapist and a } \\
\text { speech-language pathologist, by } \\
\text { means of a preventive intervention }\end{array}$ & Eclectic & \begin{tabular}{|c|} 
Pre: structured \\
questionnaire about \\
speech-language pathology \\
and physiotherapeutic \\
topics, and laryngological \\
evaluation \\
\end{tabular} & $\begin{array}{l}45 \text { min } \\
6 \text { biweekly } \\
\text { meetings }\end{array}$ & Yes \\
\hline 7 & $\begin{array}{l}\text { Pizolato et al. } \\
\text { (2012) }\end{array}$ & $\begin{array}{l}\text { Brazil/SP } \\
\text { Case study }\end{array}$ & $\begin{array}{c}6 \\
5+/ 1 \lesssim\end{array}$ & $\begin{array}{c}\text { To evaluate the effectiveness of an } \\
\text { education program on teachers' } \\
\text { voice, using a quantitative } \\
\text { research }\end{array}$ & Eclectic & $\begin{array}{l}\text { Pre: auditory-perceptual } \\
\text { analysis and structured } \\
\text { questionnaire about vocal } \\
\text { habits and complaints }\end{array}$ & $\begin{array}{l}60 \text { min } \\
5 \text { weekly } \\
\text { meetings }\end{array}$ & Yes \\
\hline 8 & $\begin{array}{l}\text { Pizolato et al. } \\
\text { (2013) }\end{array}$ & $\begin{array}{l}\text { Brazil/SP } \\
\text { Longitudinal } \\
\text { study }\end{array}$ & $\begin{array}{c}70 \\
\text { Experimental } \\
\text { group:30 } \\
26 \% / 4{ }^{\lambda} \\
\text { Control } \\
\text { group: } 40 \\
319 / 9 \hat{0}\end{array}$ & $\begin{array}{l}\text { To conduct a longitudinal } \\
\text { evaluation of the impact of voice- } \\
\text { related educational activities on } \\
\text { teachers' quality of life }\end{array}$ & $\begin{array}{l}\text { Experimental } \\
\text { group: } \\
\text { Eclectic } \\
\text { Control } \\
\text { group: } \\
\text { Indirect }\end{array}$ & $\begin{array}{c}\text { Pre and post: Brazilian } \\
\text { Voice-Related Quality of Life } \\
\text { questionnaire }\end{array}$ & $\begin{array}{l}\text { Experimental } \\
\text { group: } \\
30 \text { min; } \\
5 \text { biweekly } \\
\text { meetings } \\
\\
\text { Control group: } \\
30 \text { min; } \\
2 \text { biweekly } \\
\text { meetings }\end{array}$ & Yes \\
\hline 9 & $\begin{array}{l}\text { Kasama, } \\
\text { Martinez and } \\
\text { Navarro } \\
(2011)\end{array}$ & $\begin{array}{l}\text { Brazil/SP } \\
\text { Experimental } \\
\text { study }\end{array}$ & $\begin{array}{c}22 \\
19 ㅇ / 30^{\lambda}\end{array}$ & $\begin{array}{c}\text { To propose and to analyze an } \\
\text { action of health promotion for } \\
\text { teachers' voice, in order to provide } \\
\text { awareness and perception of the } \\
\text { factors that determine or affect the } \\
\text { process of dysphonia }\end{array}$ & Eclectic & $\begin{array}{c}\text { Pre and post: Brazilian } \\
\text { Voice-Related Quality of Life } \\
\text { questionnaire }\end{array}$ & $\begin{array}{l}60 \text { min } \\
12 \text { weekly } \\
\text { meetings }\end{array}$ & Yes \\
\hline
\end{tabular}

Figure 2. Publications according to author/year, location/type of study, sample (n), objective, assessment instrument in pre-and post-intervention, type of therapeutic approach, duration of actions and number of meetings, and intervention effectiveness 


\section{LITERATURE REVIEW}

Based on the eligibility criteria, 9 studies were found. All of them were conducted in Brazil, between 2008 and 2015 , and $11.1 \%$ were published in the last 5 years. The studies were carried out in the following regions: Southeast $(n=5)$, Northeast $(n=3)$, and Midwest $(n=1)$

Regarding the methodology employed by the studies, it was observed that two articles did not make explicit their delimitation. Therefore, based on what was analyzed by means of reading, the following methodological characteristics were determined: quantitative and qualitative approaches in combination $(\mathrm{n}=1)$, quasi-experimental $(n=1)$, action research $(n=1)$, experimental $(n=1)$, case study $(n=2)$ and longitudinal study $(n=3)$.

The number of participants in the studies ranged from 5 to 90 , with an average of 29.4 subjects. All studies used an eclectic approach, with the exception of one, which employed the indirect approach, in isolation, in a control group ${ }^{26}$. The use of this approach by the studies may be accounted by the combination of informative and practical strategies that results in a greater effectiveness, since it provides the necessary knowledge for teachers to be an agent of their own health ${ }^{11}$. The number of meetings varied from 1 to 12 , with an average of 7.1. The duration of actions varied from 30 minutes to 2 hours, with an average of 63.8 minutes of intervention. Only one study ${ }^{27}$ promoted a focal workshop, with the duration of two hours in total.

It was identified that there were several ways to designate the speech-language pathology actions promoted by the selected studies, as: weekly meetings, orientation sessions, vocal workshop, voice experience and theoretical-practical educational program. Although there were some differences in relation to the use of these terms, all studies were conducted in group and at school.

Considering the selected articles in this integrative review, it was possible to identify that the following objectives were established: to verify the impact of the actions on voice-related quality of life $(n=3)$, to analyze the teachers' voice complaints in pre-and post-intervention $(n=3)$, to verify the teachers' perception on the conducted action $(n=1)$, to explore the health situation in an interdisciplinary approach (physiotherapist and speech-language pathologist) $(n=1)$, and to describe an experience of voice education with teachers $(n=1)$.

\section{Therapeutic approaches}

The majority of the studies analyzed in this review used the eclectic approach as a methodology to the promotion and prevention of vocal health, with the exception of the above-mentioned study, which used solely the indirect approach in a control group ${ }^{26}$.

Regarding the direct approach, one study ${ }^{27}$ did not explain in the methodology which vocal techniques and exercises were used, makingthe understanding and even the reproducibility of the action difficult. In the direct approach, the most used exercises by the studies were: nasal sound $10,15,16,18,26$, vibration of the tongue/lip ${ }^{13-16}$, wild chewing ${ }^{13}$, maximum phonation time (MPT) of voiced and voiceless fricatives ${ }^{10,13-16}$, tongue rotation in the vestibule ${ }^{14}$ and yawn-sigh ${ }^{15}$; one study ${ }^{18}$ used semi-occluded vocal tract and the digital manipulation of the larynx; one study ${ }^{16}$ included in the intervention program gargling with water; and three studies ${ }^{10,15,18}$ used the chanted voice. In order to work with articulation, there were studies ${ }^{10,13,16}$ that also used tongue twisters. All the actions promoted by the studies considered activities of relaxation, stretching (cervical and/or corporal), breathing and pneumophonoarticulatory coordination ${ }^{10,12-16,18,26,27}$.

The inclusion of vocal exercises, either warm up or cool-down, provides physiologically improvements, as: greater mobility of the vocal fold mucosa, balance of vocal emission, greater vocal projection and reduction of phonatory effort ${ }^{28,29}$, that can be perceived from acoustic, auditory-perceptual, self-assessment and aerodynamic vocal measures related to phonation ${ }^{30}$.

In relation to the indirect approach, the most reported vocal hygiene guidelines were: the importance of hydration, bad vocal habits, how to deal with classroom noise, the importance of warm up and cool-down exercises, and anatomophysiology of phonation $10,12,13,15,16,18,26$. Furthermore, only one study ${ }^{18}$ included dynamics to deal with verbal and non-verbal expressivity.

One study ${ }^{31}$, that aimed at verifying the importance of non-verbal communication of teachers in classroom from the students' point of view, identified that they reported that such communication complements the content that is being addressed, demonstrating more truly what teachers think or feel. The students also highlighted that teachers' expressiveness of the body conveys safety, enthusiasm for the issue under debate, and it holds students' attention. Such findings emphasize the needto include this topic in the speech-language pathology actions for teachers' voice, since 
communication impacts directly on the teaching-learning process.

In relation to the learning acquired in the speech-language pathology actions, there were studies ${ }^{10,15,18,26}$ that aimed at reinforcing it in long term, distributing support materials with explanations about thetopics that were addressed, the exercises conducted in the actions, basic breathing tips and strategies to make vocal dynamics more flexible, similar to findings from other national ${ }^{11}$ and international ${ }^{32}$ studies.

At the end of the actions, some researchers ${ }^{10,12,16,14}$ were concerned with obtaining the opinion of the participants about the activities that were conducted and about the group modality. They found that the strategies that were used were satisfactory and positive. One of these studies ${ }^{16}$ reported that, in spite of the effectiveness of the workshops, there were teachers that considered abandoning the intervention due to lack of time and shame to perform the group exercises.RossiBarbosa et al..$^{33}$, in their study on teachers' readiness for behavior change, observed that the majority of individuals demonstrates resistance, demotivation and lack of readiness to participate in therapy or health promotion programs.

However, it is believed that the use of the group modality, in all studies that were analyzed in this review, can be explained because group actions contribute to reflection, discussion, experience sharing, and motivation of teachers, as well as it increases the chances of participation and continuity of learning after the intervention ${ }^{19,34}$. It is possible to mention, as a characteristic found in all studies, the conduction of activities in the school environment. Such space permits its configuration as a social environment for awareness

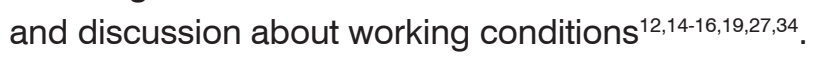

Oftentimes, those discussions about the workorganization and environment help teachers to visualize the problems related to their daily work, as well as to reflect on possible solutions. This encourages teachers to look for ways that can alleviate or solve these physical or organizational problems related to their work, by means of dialogue with the school management and/or higher instances of management, among other ways ${ }^{12,13,16}$.

\section{Assessment instruments in pre-and post-intervention}

In relation to the assessment instruments that were used by the studies, in the pre-and post-intervention periods, it was possible to verify that: four used structured questionnaires - demographic/vocal history ${ }^{12-14,16}$; three applied vocal self-assessment questionnaires ${ }^{10,15,26}$; three conducted auditory-perceptual analyses ${ }^{12,13,18}$; three promoted laryngological evaluation ${ }^{13,14,18}$; and one used acoustic analysis ${ }^{18}$ to evaluate teachers.

The most used instruments in this type of research were the structured questionnaires before conducting the vocal workshops ${ }^{12-14,16}$. The majority of the questionnaires was elaborated by the authors of the studies and aimed at considering different voice-related aspects, as well as personal and working condition information.

Some studies ${ }^{14,16}$ used this type of questionnaire because they aimed at collecting data to help the vocal workshops' future direction and planning. Therefore, the elaboration of the speech-language pathology intervention was based on the needs reported by the teachers.

Although some studies ${ }^{12,14,16,27}$ state that there was effectiveness in the actions, they do not report measurable data in results, what made the analysis for this review difficult. Those studies reported in the methodology the qualitative or descriptive aspect, focusing on the promotion of vocal health education, with the main objective of making teachers responsible for their own health.

The self-assessment instrument that was used in the speech-language pathology actions with teachers was the Brazilian Voice-Related Quality of Life questionnaire ${ }^{10,15,26}$. It was adapted to Brazilian Portuguese by Gasparini and Behlau ${ }^{35}$,from the Voice Related Quality of Life (V-RQOL), developed by Hogikyan and Sethuraman ${ }^{36}$. This questionnaire aims at analyzing the impact of dysphonia on subjects' quality of life, based on 10 items that correspond to three domains: social-emotional, physical functioning, and global. The maximum score for each domain is 100 .

Ribas, Penteado and García-Zapata ${ }^{15}$ used as one of the assessment instruments in pre-and post-intervention the above-mentioned Brazilian questionnaire. They found that, in pre-intervention, teachers showed a low impact of the voice-related quality of life on the global and physical functioning domains, and a medium impact on the social-emotional domain. After the intervention, the authors verified that there were an improvement in the global domain and a small worsening in the physical functioning and social-emotional domains. They explained these findings according to the learning and awareness processes related to vocal symptoms that are used to identify and characterize 
vocal problems. Furthermore, they suggested that the speech-language pathology actions called the attention to the relationship between voice and quality of life, so that the subjects were more critical when reevaluating themselves.

In Kasama, Martinez and Navarro ${ }^{10}$, which used the same self-assessment instrument, similar findings were obtained. They found that, before the intervention, the scores were close to 100 . However, in reevaluation, the teachers' scores varied. There were increases, maintenance and decrease in relation to some domains of the questionnaire. On the other hand, findings from Pizolato et al. ${ }^{26}$ identified that, in pre-intervention, the teachers' voice-related quality of life was not affected, even in the presence of vocal symptoms. After the speech-language pathology intervention, the groups showed a significant increase of the scores in the global domain, what revealed that the promoted actions influenced positively the quality of life of the teachers from this study.

Given the findings from those studies that used the Brazilian V-RQOL questionnaire, it is possible to infer that, on the one hand, it helps the verification of the effectiveness of the actions, and on the other hand, in some situations, this questionnaire cannot be a good indicator of success of an intervention program, as found in the study of Kasama, Martinez and Navarro ${ }^{10}$.

In relation to the auditory-perceptual analysis, some studies ${ }^{12,13,18}$ used this method to evaluate, in pre-and post-intervention, the teachers' voice quality. Regarding the instruments, it was observed the use of the GRBASI sale ${ }^{37}$ and theVisual Analog Scale (VAS) ${ }^{38}$. Silverio et al. ${ }^{13}$ used the GRBASI scale and observed that, in the production of the sustained vowel $[\varepsilon]$, in pre-intervention, $92.85 \%$ of the teachers showed a voice disorder in some degree. The most affected parameters were roughness, breathiness and strain. In post-intervention, there was a significant reduction only in the strain parameter. The authors argued that such improvement was due to changes in relation to the voice care and due to an increased understandingof the causes of strains.

Luchesi, Mourão and Kitamura ${ }^{18}$ used the VAS to evaluate the parameters: pitch, modulation and articulation. These aspects were selected with the objective to compare the auditory-perceptual and acoustic analyses. In terms of the auditory-perceptual analysis, in post-intervention, they found an increase of the values forthe three parameters. However, the difference between pre-and post-intervention for all parameters and the correlation between the two types of evaluation were not statistically significant. Pizolato et al. ${ }^{12}$ also conducted an auditory-perceptual analysis in their research, but they did not mention which tool was used and its results. They only reported the subjects' improvement in terms of strain.

When analyzing the use of the auditory-perceptual analysis by the studies of this review, it is noted that the instruments GRBASI and VAS, which were used for voice analysis in pre-and post-intervention, did not identify significant changes in the teachers. The tension reduction in post-intervention was the most mentioned achievement by the studies. However, it is important to highlight that, it is often after the intervention that teachers can perceive present vocal symptoms, due to the acquired learning from interventions about vocal health, which make them more aware ${ }^{10}$. Moreover, the way that the intervention is structured can provide no enough time to trigger teachers' voice changes ${ }^{15}$.

The laryngological evaluation conducted in the actions was reported by some studies ${ }^{13,14,18}$. The use of this exam allows the confirmation of diagnosis, promotes teachers' awareness in relation to disorders, and encourages them to look for a speech therapy treatment, according to Luchesi, Mourão and Kitamura ${ }^{18}$. However, when the studies also aims at conducting the exam in post-intervention, teachers refuse it and report discomfort with this procedure ${ }^{13}$.

The study of Silverio et al. ${ }^{13}$ used the auditory-perceptual analysis and the laryngological evaluation as instruments to evaluate teachers in the first step of the intervention. At the end of the research, they reported that the findings related to the laryngological evaluation were consistent with the complaints, laryngeal symptoms and auditory-perceptual analysis. This result highlights the importance of the association of instruments with an accurate diagnostic and the verification of altered vocal parameters according tothe pathology.

The acoustic analysis was conducted in one study ${ }^{18}$, with the objective to investigate the fundamental frequency $\left(f_{0}\right)$, the frequency range, and the first and second formants $\left(F_{1}\right.$ and $\left.F_{2}\right)$. According to the authors, the phono-articulatory parameters were selected with the aim at comparing the auditory-perceptual and acoustic analyses. However, no statistically significant correlation between the two analyses was found, since the small number of subjects and the lack of training in relation to the speech-language therapists may have influenced the results. 
However, it was possible to suggest that there was a statistically significant frequency range extension and a $F_{1}$ increase for $/ \mathrm{i} /$ and $/ \mathrm{u} /$ in post-intervention ${ }^{18}$. According to the literature ${ }^{39}$, the acoustic analysis is complementary to the auditory-perceptual analysis. It helps data quantification, correlation of perceptual judgments and even therapeutic monitoring. It is important to mention that the evaluator's previous training to use the software and interpret data is crucial $^{39}$. It was one of the factors that influenced the results from the above-mentioned research, since no previous training occurred.

\section{Duration of actions and number of meetings}

For most studies ${ }^{10,12,13,16}$, the duration of the actions that were conducted was approximately 60 minutes per workshop. In relation to the number of meetings, three studies ${ }^{10,13,18}$ conducted 12 weekly meetings. The duration and number of the actions varied depending on the objective proposed by the action and mainly on the school availability and openness for the actions. The school administration (principals and coordinators) were informed in advance about the schedule of the actions, in order to avoid disrupting the students' classes.

In the study carried out by Pizolato et al. ${ }^{12}$,the teachers reported that the contents would be acquired easier if there was more than a meeting per week. However, the authors argued that, due to the schedule provided by the school administration, it was possible to conduct only a meeting per week. Other studies ${ }^{12,16}$ mentioned that, although their actions were considered satisfactory, the teachers reported the need for a speech-language pathologist at school, in order to provide them daily assistance.

The study of Luchesi, Mourão and Kitamura ${ }^{18}$ mentions the need for the inclusion of vocal improvement courses in the professional training, in order to provide teachers with the opportunity to learn about prevention of voice disorderscaused by work-related factors.

The importance of maintaining long-term vocal health actions with those professionals, in order to ensure their follow up, what was not observed in any study of this review, should be highlighted.

\section{Intervention effectiveness}

In relation to the obtained results by the analyzed studies in this review, the majority of the authors considers as effective their voice-related speech-language pathology actions. The results are positive, satisfactory or even relevant for the quality-of-life improvement and for the professional use of voice. Furthermore, after the end of the workshops, the teachers were more motivated to recognize the importance of vocal care, to change their inappropriate habits and to conduct vocal exercises ${ }^{10,12,14,16,25,26}$.

On the other hand, some studies ${ }^{15,18}$ considered their actions as partially satisfactory, since there were aspects that affected the effectiveness. The study of Ribas, Penteado and García-Zapata ${ }^{15}$ reported that the way that the action was structured (monthly meetings) may have been insufficient to trigger significant changes in the vocal health promotion, what resulted in a minimum increase inthe physical functioning and global domains of the Brazilian V-RQOL questionnaire.

The study of Luchesi, Mourão and Kitamura ${ }^{18}$ found that the small number of subjects, the lack of training of the speech-language pathologists to conduct the acoustic and auditory-perceptual analyses, and the low sensitivity of the selected phono-articulatory parameters may have affected the results of the actions that were promoted.

In Brazil, several studies have been researching group speech-language pathology actions. However, it should be considered that this is not the reality of the course curricula from the Brazilian speech-language pathology undergraduate degrees. The inclusion of this therapeutic intervention in thesecourse curricula should be highlighted, since it may broaden the perspective of future professionals regarding the importance of health prevention and promotion, from educational and collective actions. The dialogue must be essential to transmit and share knowledge.

\section{CONCLUSION}

It could be observed that the group speech-language pathology actions for teachers' vocal health influenced the voice-related quality of life, reducing the vocal and emotional symptoms caused by several work-related factors.

The eclectic therapeutic approach was the most used one, as well as there were variations in the action duration and number of meetings among the studies. Regarding the assessment instruments, the vocal self-assessment and the auditory-perceptual analysis were most highlighted in the actions. They were used in the pre- and post-intervention, as a parameter to verify whether the intervention triggered positive 
and significant changes for teachers' vocal health. Furthermore, the majority of the studies considered their results as effective, in relation to the actions.

It should be noted that, according to the studies of this review, the therapy group at school allows the creation of a favorable environment for discussion, problem solving and socialization for teachers, promoting a supporting network and shared knowledge.

The results of this review are expected to contribute to speech-language pathologists and researchers in their decision making related to the selection of a therapy group, as well as to the elaboration of speech-language pathology actions for teachers.

\section{REFERENCES}

1. Ribas TM, Penteado RZ, García-Zapata MTA. Quality of life related with the voice of teachers: exploratory systematic review of literature. Rev. CEFAC. 2014;16(1):294-306.

2. Behlau M, Zambon F, Guerrieri AC, Roy N. Epidemiology of voice disorders in teachers and nonteachers in Brazil: prevalence and adverse effects. J Voice. 2012;26(5): 665.e18.

3. Anhaia TC, Klahr PS, Cassol M. Association between teaching experience and voice self-assessment among professors: a cross-sectional observational study. Rev. CEFAC. 2015;17(1):52-7.

4. Dragone MLS, Ferreira LP, Giannini SPP, SimõesZenari M, Vieira VP, Behlau M. Voz do professor: uma revisão de 15 anos de contribuição fonoaudiológica. Rev Soc Bras Fonoaudiol. 2010;15(2):289-96.

5. Caporossi C, Ferreira LP. Sintomas vocais e fatores relativos ao estilo de vida em professores. Rev. CEFAC. 2011;13(1):132-9.

6. Silva GJ, Almeida AA, Lucena BTL, Silva MFBL. Vocal symptoms and self-reported causes in teachers. Rev. CEFAC. 2016;18(1):158-66.

7. Servilha EAM, Costa ATF. Knowledge about voice and the importance of voice as an educational resource in the perspective of university professors. Rev. CEFAC. 2015;17(1):13-26.

8. Rodrigues ALV, Medeiros AM, Teixeira LC. Impact of the teacher's voice in the classroom: a literature review. Distúrb. Comun. 2017;29(1):2-9.

9. Costa DB, Lopes LW, Silva EG, Cunha GMS, Almeida LNA, Almeida AAF. The risk factors and emotional on the voice of teachers with and without vocal complaints. Rev. CEFAC. 2013;15(4):1001-10.
10. Kasama ST, Martinez EZ, Navarro VL. Proposta de um programa de bem estar vocal para professores: estudo de caso. Distúrb. Comun. 2011;23(1):35-42.

11. Anjos LM, Paletot YA, Souza SMA, Lima-Silva MFB. Contribuições de um programa de intervenção fonoaudiologica em voz para professores causas In: One GMC, Albuquerque HN (eds). Saúde e meio ambiente: os desafios da interdisciplinaridade nos ciclos da vida humana. Campina Grande - PB: IBEA, 2017. p.407-25.

12. Pizolato RA, Mialhe FL, Barrichelo RCO, Rehder MIBC, Pereira AC. Práticas e percepções de professores, após a vivência vocal em um programa educativo para a voz. Rev Odonto. 2012;20(39):35-44.

13. Silverio KCA, Gonçalves CGO, Penteado RZ, Vieira TPG, Libardi A, Rossi D. Ações em saúde vocal: proposta de melhoria do perfil vocal de professores. Pró-fono R. Atual. Cient. 2008;20(3):177-82.

14. Almeida KA, Nuto LTS, Oliveira GC, Holanda FEBPN, Freitas BMR, Almeida MM. Prática da interdisciplinaridade do petsaúde com professores da escola pública. Rev. Bras. Promoç. Saúde. 2012;25(1):80-5.

15. Ribas TM, Penteado RZ, García-Zapata MTA. Voicerelated quality of life: impact of a speechlanguage pathology intervention with teachers. Rev. CEFAC. 2014;16(2):554-65.

16. Xavier IALN, Santos ACO, Silva DM. Vocal health of teacher: phonoaudiologic intervention in primary health. Rev. CEFAC. 2013;5(4):976-85.

17. Almeida LNA, Fahning AKCA, Trajano FMP, Anjos UU, Almeida AAF. Group voice therapy and its effectiveness in the treatment of dysphonia: a systematic review. Rev. CEFAC. 2015;17(6):2000-8.

18. Luchesi KF, Mourão LF, Kitamura S. Efetividade de um programa de aprimoramento vocal para professores. Rev. CEFAC. 2012;14(3):459-70.

19. Souza APR, Crestani AH, Vieira CR, Machado FCM, Pereira LL. O grupo na fonoaudiologia: origens clínicas e na saúde coletiva. Rev. CEFAC. 2011;13(1):140-51.

20. Santos ACM, Borrego MCM, Bhelau M. Effect of direct and indirect voice training in SpeechLanguage Pathology and Audiology students. CoDAS. 2015;27(4): 384-91.

21. Anhaia TC, Gurgel LG, Vieira RH, Cassol M. Direct and indirect vocal interventions for teachers: a systematic review of the literature. ACR. 2013;18(4):363-8. 
22. Penteado RZ, Ribas TM. Processos educativos em saúde vocal do professor: análise da literatura da Fonoaudiologia brasileira. Rev Soc Bras Fonoaudiol. 2011;16(2):233-9.

23. Cielo CA, Cappellari VM. Tempo máximo de fonação de crianças pré-escolares. Rev Bras Otorrinolaringol. 2008;74(4):552-60.

24. Souza LBR, Pernambuco LA, Santos MM, Silva JCV. Queixa vocal, análise perceptiva auditiva e autoavaliação da voz de mulheres com obesidade mórbida. ABCD Arq Bras Cir Dig. 2015;28(supl.1):23-5.

25. Souza MT, Silva MD, Carvalho R. Revisão integrativa: o que é e como fazer. Einstein. 2010;8(1 Pt 1):102-6.

26. Pizolato RA, Rehder MIBC, Meneghim MC, Ambrosano GMB, Mialhe FL, Pereira AC. Impact on quality of life in teachers after educational actions for prevention of voice disorders: a longitudinal study. Health Qual Life Outcomes. 2013;11(28):1-9.

27. Trigueiro JS, Silva MLS, Brandão RS, Torquato IMB, Nogueira MF, Alves GAS. A voz do professor: um instrumento que precisa de cuidado. J. Res. Fundam. Care. 2015;7(3):2865-73.

28. Pereira LPP, Masson MLV, Carvalho FM. Vocal warm-up and breathing training for teachers: randomized clinical trial. Rev. Saúde Pública. 2015;49:67.

29. Cielo CA, Beber BC. Saúde vocal do teleoperador. Distúrb. Comun. 2012;24(1):109-16.

30. Ribeiro VV, Frigo LF, Bastilha GR, Cielo CA. Vocal warm-up and cool-down: systematic review. Rev. CEFAC. 2016;18(6):1456-65.

31. Sousa LFL, Leal AL, Sena EFC. A importância da comunicação não verbal do professor universitário no exercício de sua atividade profissional. Rev. CEFAC. 2010;2(5):784-7.

32. Bolbol SA, Zalat MM, Hammam RAM, Elnakeb NL. Risk factors of voice disorders and impact of vocal hygiene awareness program among teachers in public schools in Egypt. J. Voice. 2016;31(2):251. e9-251.e16.

33. Rossi-Barbosa LA, Gama ACC, Caldeira AP. Association between readiness for behavior change and complaints of vocal problems in teachers. CoDAS. 2015;27(2):170-7.

34. Penteado RZ, Pereira IMTB. Qualidade de vida e saúde vocal de professores. Rev Saúde Pública. 2007;41(2):236-43.
35. Gasparini G, Behlau M. Quality of life: validation of the Brazilian version of the voice-related quality of life (V-RQOL) measure. J. Voice. 2009;23(1):76-8.

36. Hogikyan ND, Sethuraman G. Validation of an instrument to measure voice-related quality of life (V-RQOL). J. Voice. 1999;13(4):557-69.

37. Hirano M. Clinical examination of voice. New York: Springer Verlag; 1981.

38. Yamasaki R, Madazio G, Leão SH, Padovani M, Azevedo R, Behlau M. Auditory-perceptual evaluation of normal and dysphonic voices using the Voice Deviation Scale. J. Voice. 2017;31(1):67-71.

39. Camargo Z, Madureira S, Dajer ME. Análise acústica da voz e da fala - fundamentos e aplicações na fonoaudiologia. In: Marchesan IQ, Silva $H J$, Tomé MC (orgs). Tratado das especialidades em fonoaudiologia.1.ed. São Paulo: Guanabara Koogan, 2014. cap.15. p. 204-16. 